\title{
Functional Properties of Channels Formed by the Neuronal Gap Junction Protein Connexin36
}

\author{
Midituru Srinivas, ${ }^{1}$ Renato Rozental, ${ }^{1,2}$ Takashi Kojima, ${ }^{1}$ Rolf Dermietzel, ${ }^{3}$ Mark Mehler, ${ }^{1,2}$ \\ Daniele F. Condorelli, ${ }^{4}$ John A. Kessler, ${ }^{1,2}$ and David C. Spray ${ }^{1}$
}

${ }^{1}$ Departments of Neuroscience and Neurology, Albert Einstein College of Medicine, Bronx, New York 10461, ${ }^{2}$ Department of Internal Medicine, Federal University of Goias, 74000 Goias, Brazil, ${ }^{3}$ Department of Neuroanatomy/Molecular Brain Research, Ruhr University, D-44780 Bochum, Germany, and 4Institute of Biochemistry, University of Catania, 95125 Catania, Italy

\begin{abstract}
The expression and functional properties of connexin36 (Cx36) were examined in two communication-deficient cell lines (N2Aneuroblastoma and PC-12 cells) transfected with $\mathrm{C} \times 36$ and in hippocampal neurons that express the connexin endogenously. Transfected cells expressed the expected $2.9 \mathrm{~kb}$ Cx36 transcript and Cx36 immunoreactivity, whereas nontransfected cells were devoid of $\mathrm{C} \times 36$. The relationship between steadystate junctional conductance $\left(g_{\mathrm{j}}\right)$ and transjunctional voltage was well described by a two-state Boltzmann equation. The half-inactivation voltage $\left(V_{0}\right)$, the ratio of minimal to maximal $g_{\mathrm{j}}$ $\left(g_{\min } / g_{\max }\right)$, and the equivalent gating charge were $\pm 75 \mathrm{mV}$, 0.55 , and 1.75 , respectively, indicating that $\mathrm{C} \times 36$ exhibits very low voltage sensitivity. Conductance of single Cx36 channels measured with patch pipettes containing $130 \mathrm{~mm} \mathrm{CsCl}$ was $10-15$ pS ( $n=15$ cell pairs); despite this low unitary conduc-
\end{abstract}

tance, $\mathrm{C} \times 36$ channels were permeable to the dye Lucifer yellow. Hippocampal neurons expressed Cx36 both in vivo and in culture. The electrophysiological properties of channels in cultured hippocampal neurons were similar to those of the channels expressed by the transfected cell lines, and the neuronal channels were similarly permeable to Lucifer yellow. The unique combination of weak voltage sensitivity, small unitary conductance, and permeation by anions as large as second messenger molecules endows $\mathrm{C} \times 36$ gap junction channels with properties well suited for mediating flexible electrical and biochemical interactions between neurons.

Key words: gap junction; connexin; Cx36; electrotonic synapse; electrical coupling; hippocampus; transfection; single channels; voltage sensitivity
Gap junction channels provide pathways of intercellular communication, allowing for the passage of ions and small molecules up to1 $\mathrm{kDa}$ in mass or $10-14 \mathrm{~nm}$ in diameter (Kumar and Gilula, 1996; Bruzzone and Ressot, 1997). In neurons the gap junction channels mediate electrotonic and metabolic communication (Llinás et al., 1974; Jefferys and Haas, 1982; Dermietzel and Spray, 1993; Bennett, 1997). Electrotonic coupling mediated by gap junctions has been proposed to be responsible for synchronization of signals in the inferior olive (Llinás et al., 1974) and among hippocampal CA3 neurons (MacVicar and Dudek, 1981; Taylor and Dudek, 1982), in the retina (Vaney, 1993), and during neural development (Peinado et al., 1993; Kandler and Katz, 1998; Rozental et al., 1998; Wong et al., 1998). Metabolic coupling mediated by gap junctions has been proposed to play an important role in adult neurons as well as in pattern formation during neuronal development and differentiation (Peinado et al., 1993; Kandler and Katz, 1998; Rozental et al., 1998). A single gap

Received June 1, 1999; revised Aug. 23, 1999; accepted Sept. 7, 1999.

This work was supported in part by National Institutes of Health Grants NS34931, NS07512, NS34009, NS34758 and by the F. M. Kirby Foundation (through a generous grant to the Rose F. Kennedy Center at the Albert Einstein College of Medicine). We are very grateful to Dr. Harris Ripps for providing us with the Cx35 antibody, for discussing how best to use it, and for comments on an earlier version of this manuscript; without his input much of this work could not have been completed. We also gratefully acknowledge the technical assistance of Ms. Marcia Urban, Ms. Eileen Craig, and Ms. Carmen Flores and the secretarial assistance of Ms. Frances Andrade.

Correspondence should be addressed to Dr. David C. Spray, Department of Neuroscience, 712 Kennedy Center, Albert Einstein College of Medicine, 1300 Morris Park Avenue, Bronx, NY 10461. E-mail: spray@aecom.yu.edu.

Copyright (C) 1999 Society for Neuroscience 0270-6474/99/199848-08\$05.00/0 junction channel is formed by the association of two connexons (or hemichannels) that are located in plasma membranes of adjacent cells. Each connexon is a hexameric complex of a family of protein molecules known as connexins (Cx; Kumar and Gilula, 1996; Bruzzone and Ressot, 1997). At least 15 different connexin subtypes have been identified thus far in rodents. Each connexin forms gap junction channels with unique biophysical characteristics.

In the brain a number of different connexins are expressed, including a variety in astrocytes and both $\mathrm{Cx} 32$ and $\mathrm{Cx} 45$ in oligodendrocytes (Dermietzel and Spray, 1998). In contrast, the identity of connexins that participate in the formation of gap junctions that are expressed in adult and developing neurons is not defined clearly, despite compelling functional evidence that gap junctions are expressed in various regions. Recently, O'Brien et al. (1996) cloned a novel connexin (Cx35) from the skate that is expressed at high levels in the retina; subsequently, they reported a highly homologous $\mathrm{Cx} 34.7$ from perch that is expressed in both retina and brain (O'Brien et al., 1998). Cx36, the mammalian homolog of skate and teleost Cx35, is expressed preferentially in the mouse retina and in various neuronal cell populations (Condorelli et al., 1998; Sohl et al., 1998). In situ hybridization techniques indicated high levels of Cx36 mRNA in olfactory bulbs, pineal gland, inferior olive, and CA3/CA4 hippocampal neurons, and in the retina (Condorelli et al., 1998), implying that this connexin may participate in neuronal gap junction formation. In addition, Cx36 expression was shown to be regulated developmentally (Sohl et al., 1998): highest levels of 
this transcript were detected at postnatal day 7 (P7), with a subsequent decline to lower levels in adult neurons. The spatial and temporal characteristics of $\mathrm{Cx} 36$, together with the lack of expression of this connexin in other tissues, make it the first neuron-specific connexin identified thus far.

To define the characteristics of $\mathrm{Cx} 36$ gap junction channels, we have investigated their properties in N2A and PC-12 cells after stable transfection with Cx36 cDNA. Findings from these experiments indicate that $\mathrm{Cx} 36$ forms gap junction channels with novel properties. Specifically, our results indicate that Cx36 forms gap junction channels that have the smallest unitary conductance and the weakest sensitivity to transjunctional voltage of all mammalian connexins studied to date, yet they are permeable to the dye Lucifer yellow $\left(M_{\mathrm{r}}, 454 \mathrm{kDa}\right)$. In addition, we demonstrate that hippocampal neurons express Cx36 and its mRNA and that cultured hippocampal neurons are coupled by weakly voltagedependent but Lucifer yellow-permeant channels, suggesting that this connexin is responsible for electrotonic synapses in these neurons.

\section{MATERIALS AND METHODS}

DNA construction and stable transfection. A fragment of genomic Cx36 corresponding to the full-length coding region $(-3 /+973$; numbering from the translational start site) was subcloned into the expression vector pIRES $^{\text {neo }}$ (Clontech Laboratories, Palo Alto, CA) at the NotI-EcoRI restriction sites. N2A rat neuroblastoma cells and PC-12 cells [obtained from American Type Culture Collection (Rockville, MD) and subcloned by dilution to generate parental cell lines that expressed only minimal endogenous Cx45 (N2A) or Cx37 (PC-12)] were transfected with $6 \mu \mathrm{g}$ of DNA via the Lipofectamine reagent (Life Technologies, Gaithersburg, $\mathrm{MD})$. After $48 \mathrm{hr}$ the cells were transferred to selection medium containing $0.5 \mu \mathrm{g} / \mathrm{ml}$ of G418 (Life Technologies). Individual clones were picked after 2 weeks, grown to confluence over a period of an additional 1-3 weeks, and then tested for the expression of Cx36 mRNA by Northern blot analyses (see Fig. $1 A$ ). Cells were passaged and maintained continuously in G418-containing media; early passages of cells were frozen at each splitting of confluent cultures. All cell cultures were maintained in a $37^{\circ} \mathrm{C}$ incubator in a moist $5 \% \mathrm{CO}_{2} / 95 \%$ air environment.

Northern blot analyses of transfected N2A cells and hippocampus. Total RNA was prepared from each individual clone grown in $60 \mathrm{~mm}$ dishes by using TRIZOL (Life Technologies, Grand Island, NY). Equal amounts of RNA were electrophoresed on $1 \%$ agarose/formaldehyde gels, transferred onto nitrocellulose membranes with $20 \times \operatorname{SSC}(3 \mathrm{M} \mathrm{NaCl}$ and 0.3 м Na citrate, $\mathrm{pH} 7.5$ ) for $12 \mathrm{hr}$, and fixed by UV (Stratalink, Stratagene, La Jolla, CA). ${ }^{32} \mathrm{P}$ probes were generated by using the entire $\mathrm{C} \times 36$ coding region by random priming (PRIME-IT, Stratagene) in the presence of $50 \mathrm{Ci}$ of ${ }^{32} \mathrm{P}-\mathrm{dCTP}$ (New England Nuclear, Boston, MA). Then the membranes were prehybridized for $30 \mathrm{~min}$ at $68^{\circ} \mathrm{C}$, using QuickHyb solution (Stratagene), and hybridized for $1 \mathrm{hr}$ at $68^{\circ} \mathrm{C}$. Filters were washed twice with $2 \times \mathrm{SSC} / 0.1 \% \mathrm{SDS}$ at room temperature (RT) and once in $0.1 \times \mathrm{SSC} / 0.1 \% \mathrm{SDS}$ at $60^{\circ} \mathrm{C}$ and then were exposed to $\mathrm{x}$-ray film. For comparisons of $\mathrm{Cx} 36 \mathrm{mRNA}$ levels in hippocampus at different developmental stages the blots were scanned densitometrically, and signal intensity was normalized to that of $18 \mathrm{~S}$ ribosomal RNA.

Electrophysiology. Cells transfected with Cx36 were plated at low density onto glass coverslips. Coverslips were transferred to the stage of a Nikon Diaphot microscope and bathed in a external solution containing (in mM): $140 \mathrm{NaCl}, 2 \mathrm{CsCl}, 2 \mathrm{CaCl}_{2}, 1 \mathrm{MgCl}_{2}, 5 \mathrm{HEPES}, 4 \mathrm{KCl}, 5$ dextrose, 2 pyruvate, and $1 \mathrm{BaCl}_{2}, \mathrm{pH}$ 7.2. Junctional conductance was measured between cell pairs by the dual whole-cell voltage-clamp technique with Axopatch 1C or 1D patch-clamp amplifiers (Axon Instruments, Foster City, CA). Each cell of a cell pair was voltage-clamped with patch pipettes pulled on a Flaming/Brown Micropipette puller (model P-87, Sutter Instrument, Novato, CA). The patch electrodes had resistances of 4-7 M $\Omega$ when filled with internal solution containing (in $\mathrm{mm}$ ): $130 \mathrm{CsCl}, 10 \mathrm{EGTA}, 0.5 \mathrm{CaCl}_{2}, 3 \mathrm{MgATP}, 2 \mathrm{Na}_{2} \mathrm{ATP}$, and 10 HEPES, pH 7.2. All experiments were performed at RT $\left(20-23^{\circ} \mathrm{C}\right)$. The osmolarities of external and internal solutions measured by using the freezing point method (Micro-osmette, Precision Instruments, Natick, MA) were $285 \pm 5 \mathrm{mOsm}$. Macroscopic and single-channel recordings were filtered at $0.1-1 \mathrm{kHz}$ and sampled at $1-5 \mathrm{kHz}$. Data acquisition and analysis were performed with pCLAMP6 software (Axon Instruments).

Each cell of a pair initially was held at a common holding potential of $0 \mathrm{mV}$. Thereafter, voltage pulses of variable duration and amplitude were applied to one cell to establish a transjunctional voltage gradient $\left(V_{\mathrm{j}}\right)$, and the instantaneous and steady-state junctional current was measured in the second cell (held at $0 \mathrm{mV}$ ). Steady-state junctional conductance $\left(g_{\mathrm{ss}}\right)$ at each voltage was normalized relative to the instantaneous current, and these $G_{\mathrm{j}, \text { ss }}$ values were plotted as a function of $V_{\mathrm{j}}$. The relationship between $G_{\mathrm{j}, \mathrm{ss}}$ and $V_{\mathrm{j}}$ was fit assuming a two-state Boltzmann equation (Spray et al., 1981):

$$
G_{\mathrm{j}, \mathrm{SS}}=\left\{\left(G_{\max }-G_{\min }\right) /\left(1+\exp \left[A\left(V_{\mathrm{j}}-V_{\mathrm{o}}\right)\right]\right\}+G_{\min },\right.
$$

where $V_{0}$ is the voltage at which the conductance is half-maximal, $G_{\max }$ is the maximum normalized conductance, $G_{\min }$ is the normalized voltage-insensitive residual conductance, and $A$ is a parameter defining the steepness of voltage sensitivity ( $A=n q \mathrm{~F}$, where $n$ is the equivalent number of gating charges of valence $q$, and $\mathrm{F}$ is the Faraday constant). Unitary current events were recognized as simultaneously occurring equal-sized events of opposite polarity in the current recording of each cell; these events were measured from freshly split cell pairs and in individual clones in which the incidence of coupling was low. All-points amplitude histograms of data were constructed for each experiment and fit to gaussian functions to determine the mean and variance of the baseline and open channel current. Unitary conductances were measured by fitting a linear function to the single-channel current-voltage relation.

Dye coupling. Lucifer yellow $\mathrm{CH}[5 \%(\mathrm{w} / \mathrm{v})$ in $150 \mathrm{~mm} \mathrm{LiCl}]$ was injected through a sharp microelectrode $(\sim 20 \mathrm{M} \Omega$ if filled with $3 \mathrm{M} \mathrm{KCl})$ into one cell of a cluster of N2A or PC-12 Cx36 transfectants, using short hyperpolarizing current pulses (Model M4A patch-clamp amplifier, Warner Instruments, Hamden, CT). Dye transfer in clusters or in cell pairs was visualized with a Nikon Diaphot inverted microscope equipped with xenon epifluorescence illumination and an FITC filter set. Phase contrast and fluorescence micrographs were recorded 1-2 min after dye injection by exposing Kodak TMAX 400 film.

Western blot analyses. Dishes were washed twice with PBS, and $300 \mu \mathrm{l}$ of the buffer [ $1 \mathrm{~mm} \mathrm{NaHCO}$ and $2 \mathrm{~mm}$ PMSF (Sigma)] was added to 60 $\mathrm{mm}$ dishes. The cells were scraped and collected in Eppendorf tubes and then sonicated for $10 \mathrm{sec}$. Hippocampi were removed from adult brain and sonicated in the buffer. Protein concentration was measured by using a protein assay kit (Pierce Chemical, Rockford, IL). Then $20 \mathrm{gm}$ of protein of each sample was applied per lane and separated by electrophoresis in a $10 \%$ SDS-polyacrylamide gel (Bio-Rad, Richmond, CA). After electrophoretic transfer to a nitrocellulose membrane (Bio-Rad), the membrane was saturated overnight at $4^{\circ} \mathrm{C}$ with a blocking buffer $(25$ mM Tris, $\mathrm{pH} 8.0,125 \mathrm{~mm} \mathrm{NaCl}, 0.1 \%$ Tween 20, and 4\% skim milk) and incubated with monoclonal anti-Cx35 antibody at RT for $1 \mathrm{hr}$. The membrane was incubated with a horseradish peroxidase (HRP)-conjugated anti-rabbit IgG (Vector Laboratories, Burlingame, CA) at RT for $1 \mathrm{hr}$, and the detection was performed with an enhanced chemiluminescence (ECL) Western blotting system (Amersham, Buckinghamshire, UK).

Immunocytochemical microscopy. The ABC method was used for the labeling of cryostat sections of the hippocampal region (Vector Laboratories). In brief, unfixed samples of adult rat brains were cut at $-30^{\circ} \mathrm{C}$, collected on poly-L-lysine-coated coverslips, and stored at $-20^{\circ} \mathrm{C}$ until use. Before immunoincubation the slices were fixed in $100 \%$ ethanol for 20 min, rinsed in PBS, and blocked with $0.1 \%$ BSA, followed by incubation for $46 \mathrm{hr}$ with primary anti-Cx35 antibodies at $4^{\circ} \mathrm{C}$. Then the sections were incubated with biotinylated goat anti-rabbit secondary antibody for $24 \mathrm{hr}$. Finally, after washing and blocking, the sections were incubated for $4 \mathrm{hr}$ with the avidin-biotinylated peroxidase complex. Peroxidase activity was visualized with $3,3^{\prime}$ diaminobenzidine, followed by enhancement with $0.1 \%$ osmium tetroxide.

In situ hybridization. In situ hybridization was performed as described (Zhang et al., 1998). Sections were post-fixed in $0.1 \mathrm{M}$ sodium phosphatebuffered $4 \%$ paraformaldehyde, $\mathrm{pH} 7.4$, for $30 \mathrm{~min}$, rinsed in PBS for 1 min and in $2 \times$ SSC for $1 \mathrm{~min}$, acetylated with $0.5 \%$ acetic anhydride in $0.1 \mathrm{~m}$ triethanolamine, $\mathrm{pH} 8.0$, for $10 \mathrm{~min}$, and rinsed again in $2 \times \mathrm{SSC}$ and then in PBS, with final dehydration in a graded series of ethanol washes. The slides were prehybridized in $2 \times \mathrm{SSC}$ and $50 \%$ formamide at $50^{\circ} \mathrm{C}$ for $2 \mathrm{hr}$ and hybridized with hybridization buffer containing $2 \times 10^{4}$ $\mathrm{cpm} / \mu \mathrm{l}$ cRNA probe [the hybridization buffer contained $0.75 \mathrm{M} \mathrm{NaCl}$, $50 \%$ formamide, $1 \times$ Denhardt's, $10 \%$ dextran sulfate, $30 \mathrm{~mm}$ DTT, 10 mu Tris-HCl, $\mathrm{pH}$ 7.5, $1 \mathrm{~mm}$ EDTA, $100 \mu \mathrm{g} / \mathrm{ml}$ salmon sperm DNA, and $0.5 \mathrm{mg} / \mathrm{ml}$ yeast tRNA] at $50^{\circ} \mathrm{C}$ for $16 \mathrm{hr}$. Then the slides were washed 
A

Figure 1. Expression of Cx36 mRNA and functional coupling in transfected N2A and PC-12 cells. $A$, Northern blot analyses of individually selected clones of stable transfectants. The arrow indicates the expected size of the transfected $\mathrm{Cx} 36$ transcript. $B$, Functional expression of coupling strength in several N2A and PC -12 cell clones as evaluated by dual whole-cell recordings. Note that the scale for junctional conductance $\left(g_{\mathrm{j}}\right)$ is logarithmic to illustrate effectively the range of $g_{\mathrm{j}}$ values. The numbers of clones correspond to those of the Northern blots displayed in $A$. The number of cell pairs evaluated and the percentage of these pairs in which coupling was present is given in Results. $C-F$, Coupling between Cx36 transfectants demonstrated by Lucifer yellow passage. In Cx36-transfected $\mathrm{N} 2 \mathrm{~A}(C, D)$ and PC-12 cells $(E, F)$ dye coupling was observed frequently. In the cell pair in the top left corner in $E$ and $F$, a junctional conductance value of $9 \mathrm{nS}$ subsequently was measured by using the dual whole-cell voltage-clamp technique.
B

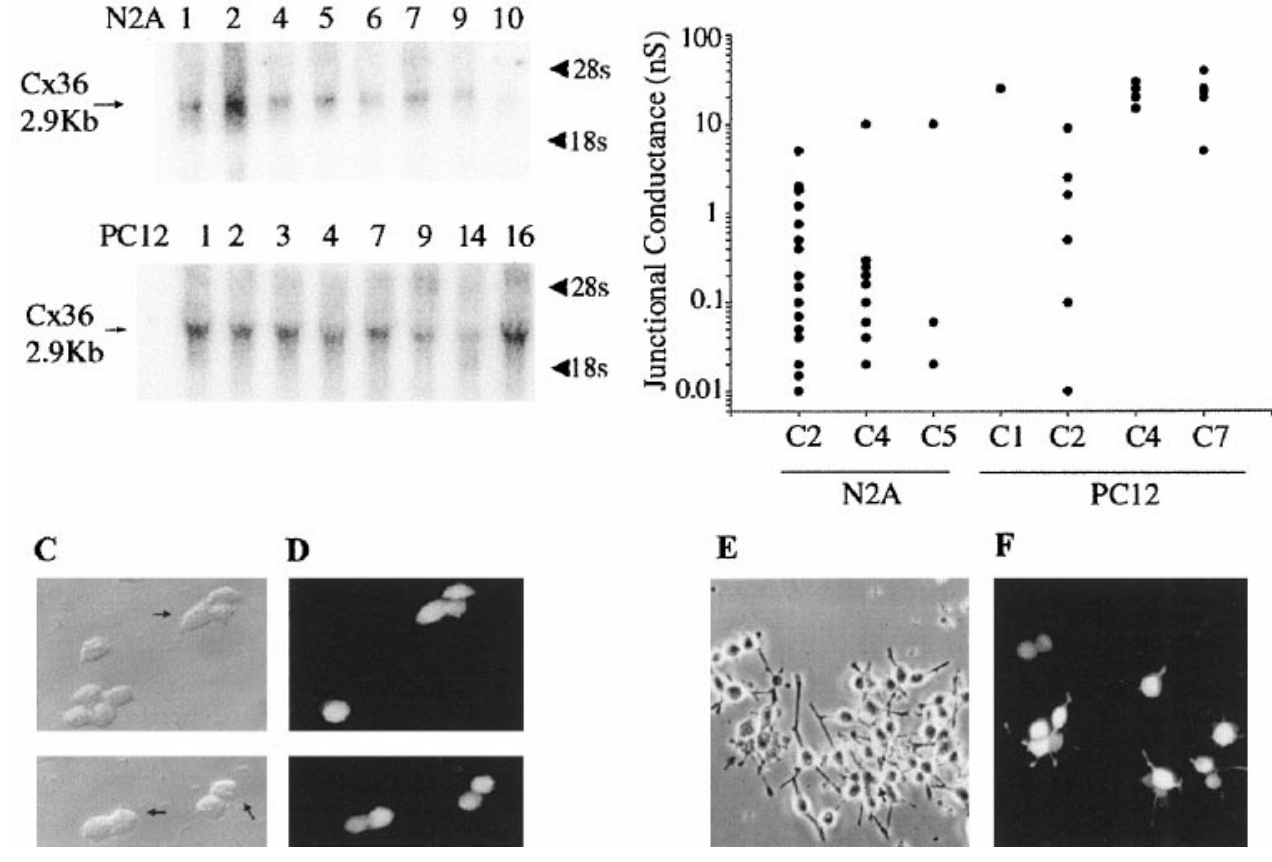

twice in $2 \times \mathrm{SSC}$ for $2 \mathrm{~min}$; in $2 \times \mathrm{SSC}, 50 \%$ formamide, and $0.1 \%$ $\beta$-mercaptoethanol (BME) at $50^{\circ} \mathrm{C}$ for $1 \mathrm{hr}$; in $20 \mu \mathrm{g} / \mathrm{ml} \mathrm{RNase} \mathrm{A}$ at $37^{\circ} \mathrm{C}$ for $30 \mathrm{~min}$ in $0.5 \mathrm{M} \mathrm{NaCl}$ and $10 \mathrm{~mm}$ Tris- $\mathrm{HCl}, \mathrm{pH} 8.0$; in $2 \times \mathrm{SSC}, 50 \%$ formamide, and $0.1 \% \mathrm{BME}$ at $58^{\circ} \mathrm{C}$ for $30 \mathrm{~min}$; and in $0.1 \times \mathrm{SSC}$ and $0.1 \% \mathrm{BME}$ at $63^{\circ}$ for $30 \mathrm{~min}$, with final dehydration. Then the sections were exposed to $\mathrm{x}$-ray film for $4-5 \mathrm{~d}$ to obtain autoradiograms. Use of the sense riboprobe confirmed the specificity of labeling.

Ribonuclease protection assay. A $562 \mathrm{bp}$ antisense riboprobe for $\mathrm{Cx} 36$ was generated from the expression plasmid by using NotI and XhoI in 25 $\mu \mathrm{l}$ of buffer containing (in mM): 200 Tris-Cl, $\mathrm{pH} 7.5,30 \mathrm{MgCl}, 10$ spermidine, $50 \mathrm{NaCl}, 0.4 \mathrm{ATP}, 0.4 \mathrm{GTP}, 0.4 \mathrm{UTP}$, and 20 DTT plus 10 $\mathrm{ml}$ of $\alpha^{32} \mathrm{P}-\mathrm{CTP}, 800 \mathrm{Ci} / \mathrm{mmol}, 20 \mathrm{U}$ of ribonuclease inhibitor, $0.5 \mathrm{mg}$ of template, and $20 \mathrm{U}$ of T7 RNA polymerase. The mixture was incubated at $37^{\circ} \mathrm{C}$ for $60 \mathrm{~min}$. Probes were purified by gel filtration. mRNA from mouse brains $(20 \mu \mathrm{g})$ was hybridized with $5 \times 10^{5} \mathrm{cpm}$ of RNA probe at $60^{\circ} \mathrm{C}$ overnight. The mixture was digested with $40 \mu \mathrm{g} / \mathrm{ml}$ ribonuclease A and $2 \mathrm{mg} / \mathrm{ml}$ ribonuclease T1. Hybridized RNAs were run on 5\% polyacrylamide gels and visualized by autoradiography.

RT-PCR analysis. RT-PCR assays on RNA isolated from primary cultures of mouse embryonic day 18 (E18) hippocampal neurons kept in culture obtained with the method described by Banker and Cowan (1977) and from adult mouse retina were performed with the Thermoscript RT-PCR System (Life Technologies). RNA was treated with DNase I (Boehringer Mannheim, Indianapolis, IN) to eliminate contamination with residual genomic DNA. Oligonucleotides corresponding to the $\mathrm{C}$ terminal of Cx36 were synthesized by Gene Link (Thornwood, NY). Routinely, 22 bp sense and 18 bp antisense primers were used: $5^{\prime}$-GAG CAA ACG AGA AGA TAA GAA G-3' and 3'-TGG ATG ATG TAG AAG CGG- $5^{\prime}$. These primers were designed to produce a fragment of $195 \mathrm{bp}$. PCR reactions contained 1-2 $\mu \mathrm{g}$ of first-strand cDNA, $50 \mu \mathrm{M}$ of sense and antisense primers, $5 \mu \mathrm{l}$ of $10 \times$ PCR buffer, $1.5 \mathrm{~mm} \mathrm{MgCl}_{2}, 1$ $\mu \mathrm{l}$ of $10 \mathrm{~mm}$ dNTP, and 2.5 U Taq Polymerase (Life Technologies) in a final volume of $50 \mu \mathrm{l}$. Thirty cycles were performed on the samples with the use of a PTC-100 Thermocycler (M. J. Research, Watertown, MA) as follows: (1) denaturation at $94^{\circ} \mathrm{C}$ for $30 \mathrm{sec},(2)$ annealing at $55^{\circ} \mathrm{C}$ for $30 \mathrm{sec}$, and (3) extension at $72^{\circ} \mathrm{C}$ for $30 \mathrm{sec}$. This was followed by a final extension cycle at $72^{\circ} \mathrm{C}$ for $8 \mathrm{~min}$ and a soak cycle at $4^{\circ} \mathrm{C}$. Reaction products were analyzed by electrophoresis on $2 \%$ agarose gels.

\section{RESULTS}

Expression levels, transcript size, and strength of functional coupling in Cx36 transfectants

To study the functional properties of connexin36 in mammalian cells, we stably transfected communication-deficient N2A and
PC-12 cells with a vector containing the full-length coding region of mouse Cx36 cDNA, as described in Materials and Methods. Numerous clones surviving selection were picked and grown for additional studies. Of these, N2A clones 1, 2, 4, 5, 6, 7, and 9 expressed an mRNA with a size expected for the exogenous transcript $(2.9 \mathrm{~kb})$ as determined by Northern blot analyses. Similarly, eight clones from PC-12 cells expressed Cx36 mRNA. A representative Northern blot for $\mathrm{Cx} 36$ in N2A and PC-12 cells is shown in Figure $1 A$, indicating that $\mathrm{N} 2 \mathrm{~A}$ clone 2 expressed high levels of Cx36 mRNA. Expression of Cx36 mRNA was moderate in N2A clones 4 and 5 and low in clones 9 and 10. Levels of Cx36 mRNA were similar in most of the clones (moderate in clones 1-4 and 7, lower in 9 and 14, and highest in 16) picked from PC-12 cells (Fig. 1 $A$ ).

To evaluate the strength of functional coupling, we determined junctional conductance between cell pairs, using the dual wholecell voltage-clamp technique. Electrical coupling in Cx36-N2A clones 2 and 4 was evident in $65 \%(n=80)$ and $50 \%(n=35)$ of cell pairs, whereas in clone 5 electrical coupling was evident in $25 \%(n=20)$ of the cell pairs. The junctional conductance $\left(g_{\mathrm{j}}\right)$ in these clones ranged from $15 \mathrm{pS}$ to $12 \mathrm{nS}$ (Fig. 1B). Cx36transfected PC -12 cell pairs were coupled also, with those from clone 2 exhibiting the widest range of junctional conductance values (Fig. 1B). Electrical coupling in Cx36-PC-12 clones 1, 2, 4, and 7 was evident in $9 \%(n=20), 34 \%(n=20), 25 \%(n=20)$, and $33 \%(n=20)$ of cell pairs, respectively.

\section{Lucifer yellow dye transfer}

Functional coupling of Cx36-transfected cells was characterized further by evaluating the permeability to Lucifer yellow, a highly fluorescent anionic dye with a molecular weight of $454 \mathrm{kDa}$. Lucifer yellow was injected through a microelectrode into individual cells within clusters of Cx36-transfected N2A and PC-12 cells, and the spread of Lucifer yellow into surrounding cells was monitored as described in Materials and Methods. Consistent with the high incidence of moderate electrical coupling in cell pairs of N2A clone 2 and PC-12 clone 2, the spread of Lucifer 
yellow dye was detected in clusters under these conditions. Dye coupling was generally weak in the $\mathrm{N} 2 \mathrm{~A}$ transfectants $(28 \% ; n=$ 29; Fig. $1 C, D$ ). Dye coupling was stronger (to more cells within the clusters) and was observed more frequently in PC-12 cells (42\%; $n=42$; Fig. $1 E, F)$. Dye coupling was not observed in N2A cells that were not transfected with $\mathrm{Cx} 36$, whereas in nontransfected PC-12 cells the dye coupling was observed only in $6 \%$ of the cell clusters. These results indicate that $\mathrm{Cx} 36$ channels are permeable to Lucifer yellow.

\section{Voltage sensitivity of Cx36 junctional conductance}

To determine the sensitivity of junctional conductance $\left(g_{\mathrm{j}}\right)$ to transjunctional voltage $\left(V_{\mathrm{j}}\right)$ in Cx36-transfected cells, we applied pulses of moderate duration $(7-10 \mathrm{sec})$ from a holding potential of $0 \mathrm{mV}$ to different voltages ranging from -110 to $110 \mathrm{mV}$ to one cell of a pair; junctional currents $\left(I_{\mathrm{j}}\right.$ traces, Fig. $\left.2 A\right)$ were measured in the unstepped cell. The instantaneous $\left(I_{\mathrm{j}, 0}\right)$ junctional currents (peak values at the start of the pulses) were found to vary linearly with transjunctional voltage; in contrast, $I_{\mathrm{j}, \mathrm{ss}}$ (the $I_{\mathrm{j}}$ values at the end of the voltage pulses) showed rectification at -60 $\mathrm{mV}>V_{\mathrm{j}}>60 \mathrm{mV}$.

The dependence of the normalized steady-state $g_{\mathrm{j}}\left(G_{\mathrm{j}, \mathrm{Ss}}\right)$ on $V_{\mathrm{j}}$ is shown in Figure $2 B . G_{\mathrm{j}, \mathrm{Ss}}$ was obtained by dividing the steadystate $I_{\mathrm{j}, \mathrm{ss}}$ by $I_{\mathrm{j}, 0}$ for each $V_{\mathrm{j}} . G_{\mathrm{j}, \mathrm{SS}}$ data for $V_{\mathrm{j}}$ values of each polarity were well fit to a two-state Boltzmann relationship (see Eq. 1, Materials and Methods). The best fit for the Boltzmann equation for the average $G_{\mathrm{j}, \mathrm{SS}}$ values ( $n=10$; SE values indicated for each $G_{\mathrm{j}, \mathrm{Ss}}$ value) is shown as a solid line. The following values for the Boltzmann parameters were obtained: $G_{\min }=0.52, V_{0}=-78$ $\mathrm{mV}$, and $A=0.07$ (gating charge $=1.75$ ) for pulses of negative polarity; $G_{\min }=0.53, V_{0}=73 \mathrm{mV}$, and $A=0.06$ (gating charge $=$ 1.5) for positive polarity. Similar properties were obtained for Cx36-transfected PC-12 cells (data not shown). These results indicate that in both transfected cell lines Cx36 forms gap junction channels that are only weakly sensitive to transjunctional voltage.

\section{Single-channel conductance of Cx36 gap junction channels}

For cells expressing other gap junction proteins, single-channel currents are generally discernible when junctional conductance is $<200$ pS. In contrast, discrete current steps were not evident in our measurements from Cx36-transfected N2A cell pairs in which $g_{\mathrm{j}}$ was low, even when large transjunctional voltages were applied (a representative example from a cell pair with $70 \mathrm{pS}$ junctional conductance in response to a $V_{\mathrm{j}}$ of $140 \mathrm{mV}$ is depicted in Fig. $3 A$ ). This finding suggests that even a $70 \mathrm{pS}$ junctional membrane is formed by so many channels that their ensemble activity obscures the individual events; thus the unitary conductance of Cx36 must be unusually low. Two sets of observations set the upper limit for the unitary conductances of $\mathrm{Cx} 36$ channels. First, we have recorded from a number of cell pairs in which $g_{\mathrm{j}}$ was $\sim 10-15 \mathrm{pS}$, and we have recorded from no cell pairs in which $g_{\mathrm{j}}$ was lower yet above the noise level of our instruments (which allows resolution of $<5 \mathrm{pS}$ events at $100 \mathrm{mV}$ ), setting $10-15 \mathrm{pS}$ as the upper limit for the value of the single-channel conductance. Junctional currents obtained from cell pairs with such low conductances are illustrated in Figure 3, $C$ and $D$, and an all-points histogram of the Figure $3 C$ trace is shown in Figure $3 E$. Second, we have measured the amplitudes of current transitions recorded while exposing low-conductance cell pairs to $3 \mathrm{~mm}$ halothane, which has been shown to decrease the open probability of other gap junction
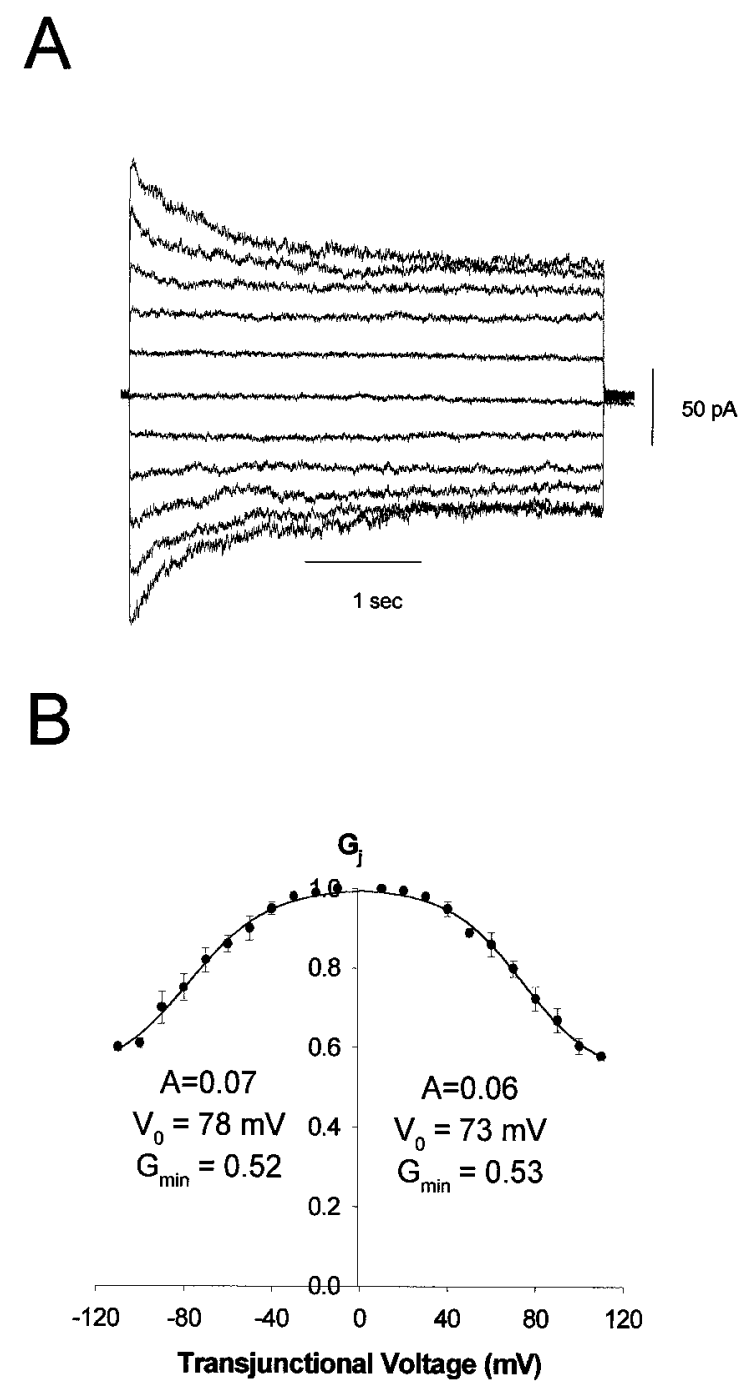

Figure 2. Voltage sensitivity of junctional currents in Cx36-transfected N2A cells. $A$, Family of junctional currents recorded in response to transjunctional voltage pulses $\pm 100 \mathrm{mV}$ in $20 \mathrm{mV}$ steps. Note that, for larger pulses, junctional currents decline exponentially toward non-zero steady-state levels. $B$, Voltage sensitivity of junctional conductance in Cx36-transfected N2A cells. Steady-state junctional conductance $\left(G_{\mathrm{j}, \mathrm{ss}}\right)$, normalized to instantaneous values, is plotted as a function of transjunctional voltage $\left(V_{\mathrm{j}}\right)$. Each point represents the mean, and the bars represent the SEM of values obtained from 10 cell pairs. The smooth line superimposing the points is a Boltzmann curve, with parameters $g_{\min } / g_{\max }=0.55$, $V_{0}= \pm 75 \mathrm{mV}$, and $A$ (slope factor) $=0.065(n=1.75$ equivalent gating charges).

channels without affecting their unitary conductances (Burt and Spray, 1989). In all cases the application of halothane completely abolished the junctional current. Unitary events that were resolved during the washout of halothane are shown in Figure $3 B$. In response to voltage ramps from -100 to $100 \mathrm{mV}$, openings of a channel to $1.5 \mathrm{pA}$ level as well as partial closure of the channel could be detected (Fig. 3B, middle trace). Application of successive ramps revealed the opening of a second channel (dotted line, bottom trace). Measurements in $>12$ cell pairs have indicated that the unitary conductance of $\mathrm{Cx} 36$ channels is $<15 \mathrm{pS}$ and may even be as low as $10 \mathrm{pS}$. However, it should be noted that the smaller value may represent a channel substate; because the ratio of $g_{\min } / g_{\max }$ is so high, substate conductance is expected to be a 


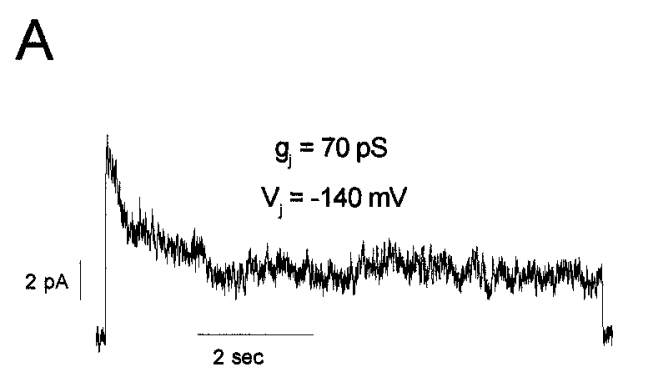

Figure 3. Unitary conductances of $\mathrm{Cx} 36$ channels. $A$, Discrete current transitions are not resolvable in a $\mathrm{Cx} 36$ gap junction where $g_{\mathrm{j}}=70 \mathrm{pS}$ in response to large transjunctional voltages, implying that unitary current transitions are quite small. $B$, Unitary current transitions measured in response to a $V_{\mathrm{j}}$ ramp $( \pm 00 \mathrm{mV}, 7 \mathrm{sec}$ duration) while halothane was rinsed from the preparation. Transitions ranging from 10 to $15 \mathrm{pS}$ were observed. $C, D$, Junctional currents in very poorly coupled cell pairs. An all-points histogram of the recording in $C$ is displayed in $E$, revealing that unitary junctional conductance $\left(\gamma_{\mathrm{j}}\right)$ is $<15 \mathrm{pS}$. $D$, Transitions recorded in response to a large trans-junctional voltage range from $\sim 8$ to $15 \mathrm{pS}$.

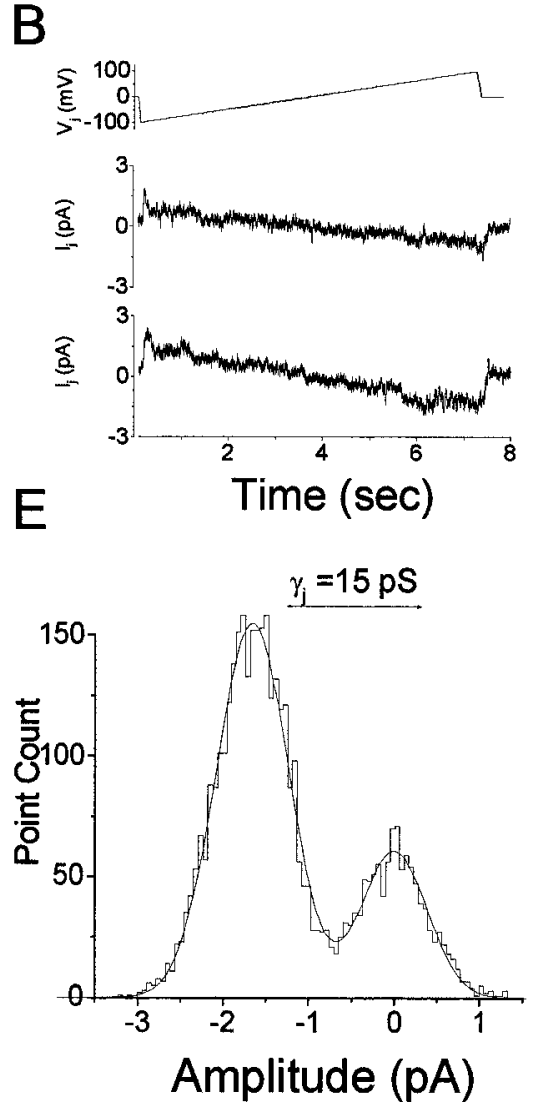

large fraction of mainstate unitary conductance (Moreno et al., 1994; Valiunas et al., 1997).

\section{Expression of Cx36 in neonatal rat brain}

To explore in more detail the expression of Cx36 in brain tissue, we performed in situ hybridization and RNase protection assays on postnatal rat brains (P7). As is illustrated in Figure 4, in situ hybridization signals were strongly localized to the superficial layers of the neocortex, the olfactory bulb (Fig. 4A), and the CA4-CA2 regions of the hippocampus (Fig. $4 B$ ). In the cerebellum a strong signal was detected in the Purkinje cell layer and in the molecular layer (Fig. $4 C$ ). Signals were virtually absent in cortical white matter (Fig. $4 A, B$ ) and in brain sections hybridized with sense construct (Fig. 4D). In situ hybridization signals were much lower in adult brain (data not shown). Nuclease protection assays performed on material from these regions in newborn (P7) rat confirmed $\mathrm{Cx} 36$ expression in olfactory cortex and hippocampus and its absence in cortical white matter (Fig. 4E). As previously reported (Sohl et al., 1998), Cx36 mRNA expression is regulated developmentally. As shown in Figure $4 F$, expression in mouse hippocampus is highest at E18 and P0 and lower in adult.

Although Cx36-specific antibodies are not yet available, a polyclonal antibody has been raised against the intracellular loop domain of the closely related skate Cx35 (O'Brien et al., 1998). Western blot analyses shown in Figure $5 A$ demonstrate that these antibodies recognize a discrete $36 \mathrm{kDa}$ band in protein obtained from Cx36-transfected N2A cells (lane 3) and from adult rat hippocampus (lane 1). A very faint signal was detected in parental N2A cells (lane 2), which are neuroblastoma in origin, whereas a signal was absent in the liver (lane 4). Staining of brain sections revealed immunoreactivity in pyramidal cells of rat hippocampus
(Fig. $5 B$ ), with significantly less reactivity in the granular layer of the dentate gyrus.

\section{Functional expression of Cx36 in cultured hippocampal neurons}

RT-PCR analyses of mRNA collected from cultured mouse hippocampal neurons revealed the presence of $\mathrm{Cx} 36$ that was maintained over 2 weeks in culture (Fig. 6A). As was found for the Cx36 N2A and PC-12 transfectants, hippocampal neurons were dye-coupled. The incidence of coupling was low during the first $2 \mathrm{~d}$ of culture, increased during the next week, and then declined to a low steady-state level $(7 \% ; n=58)$. Electrophysiological recordings from pairs of coupled hippocampal neurons revealed an average junctional conductance of $1.53 \pm 0.43 \mathrm{nS}$. A representative recording is shown for one of these cell pairs in Figure $6 C$. Note the low degree of relaxation of junctional currents in response to even very large transjunctional voltages, which is even more apparent in the steady-state $G_{\mathrm{j}, \mathrm{Ss}}-V_{\mathrm{j}}$ plot shown in Figure $6 D$, obtained from four pairs of hippocampal neurons.

\section{DISCUSSION}

We have stably transfected N2A and PC-12 cells with cDNA encoding $\mathrm{Cx} 36$ and have characterized the biophysical properties of clones expressing moderate and low levels of Cx36 mRNA. The results of this study demonstrate that Cx36 gap junction channels have an extremely small single-channel conductance (mainstate $\gamma_{\mathrm{j}} \leq 15 \mathrm{pS}$ ) and are only weakly sensitive to transjunctional voltage. In addition, we demonstrate that $\mathrm{Cx} 36$ is expressed in hippocampal neurons in situ and in culture and that gap junctional conductance between hippocampal neurons displays voltage sensitivity similar to that of Cx36-transfected cells. 

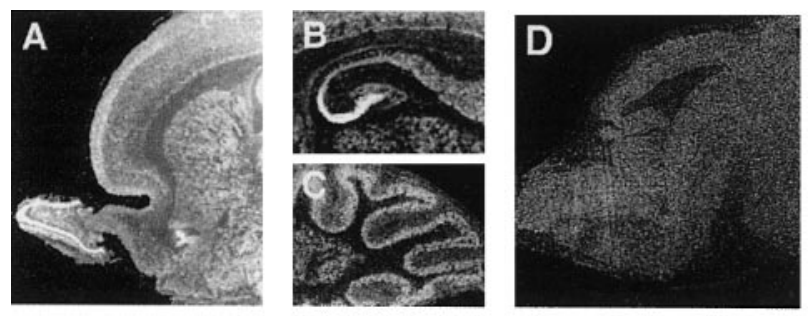

$\mathbf{E}$

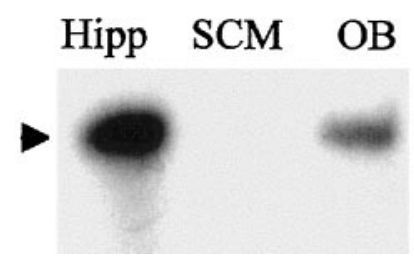

$\mathbf{F}$

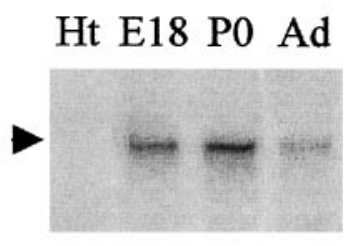

Figure 4. Cx36 mRNA expression in brain. $A-D$, In situ hybridization of Cx36 mRNA expression in the $\mathrm{P} 7$ brain. $A$, Note the abundant expression in the superficial layers of the developing cortex and in the olfactory bulb. Also note that expression is virtually absent in the subcortical white matter. $B$, Expression in the hippocampus is particularly prominent in the CA4 and CA 3 regions and less abundant in the CA1 and the dentate areas. $C, \mathrm{Cx} 36 \mathrm{mRNA}$ in the cerebellum is abundant in the Purkinje cell and the molecular layer. $D$, Sense control shows no specific labeling. $E$, Nuclease protection assay for $\mathrm{Cx} 36$ mRNA expression in the P7 brain. Expression is moderately abundant in the hippocampus (Hipp) and olfactory bulb $(O B)$ but undetectable in subcortical white matter $(S C M)$. Then $20 \mu \mathrm{g}$ of total mRNA was loaded onto each lane. $F$, Northern Blot analyses of Cx36 expression in mouse hippocampus at different stages of development. Expression of Cx36 is high at stage E18 and P0 hippocampus and declines thereafter in the adult $(A d)$. Cx36 is absent in the mouse heart $(H t)$.

Unitary conductance of $\mathrm{Cx} 36$ channels was measured in $\mathrm{N} 2 \mathrm{~A}$ cells in which expression of $\mathrm{Cx} 36$ and its mRNA were low to moderate. Our results indicate that $\mathrm{Cx} 36$ forms gap junction channels with an unusually low unitary junctional conductance $\left(\gamma_{\mathrm{j}}\right)$. In poorly coupled cell pairs $\left(g_{\mathrm{j}}=60-100 \mathrm{pS}\right)$ the junctional current did not exhibit clear transitions even when very large $V_{\mathrm{j}}$ values were imposed $(>100 \mathrm{mV})$. Instead, the junctional currents clearly exhibited a decline to a steady-state level, suggesting the presence of several channels. The absence of clear transitions even when the junctional conductance was low gave us the first indication that the unitary conductance of Cx36 is likely to be extremely small. Resolution of unitary events after the application of halothane, a strategy that has been successful for other connexins, indicated a unitary event corresponding to a $\gamma_{\mathrm{j}}$ of $<15$ pS (see Fig. $3 B$ ). In extremely poorly coupled cell pairs $\left(g_{\mathrm{j}}=\right.$ $15-40 \mathrm{pS}$ ), we also detected a $\gamma_{\mathrm{j}}$ value of $\sim 15 \mathrm{pS}$. We believe that these values represent only an estimate of the exact unitary conductance. The absence of clearly observable transitions even at very high $V_{\mathrm{j}}$ values suggests that this value represents only an upper limit. Openings and closings of $\mathrm{Cx} 36$ gap junction channels were observed only in a few of our recordings. Figure $3 D$ represents one such case in which unitary events corresponding to 8-10 $\mathrm{pS}$ were observed at a $V_{\mathrm{j}}$ of $100 \mathrm{mV}$.

Unitary conductances previously measured for gap junction channels stably expressed in mammalian cells range from $30 \mathrm{pS}$ (human and chick Cx45; Veenstra et al., 1994; Moreno et al., 1995) to 300 pS (human Cx37; Reed et al., 1993). Thus, Cx36 forms gap junction channels with the smallest unitary conductance value known to date. For neuronal coupling a channel with
A

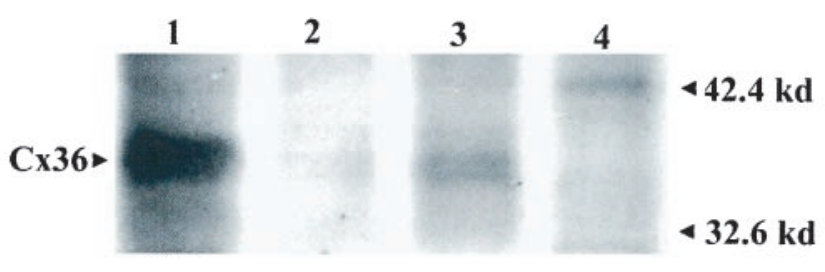

B

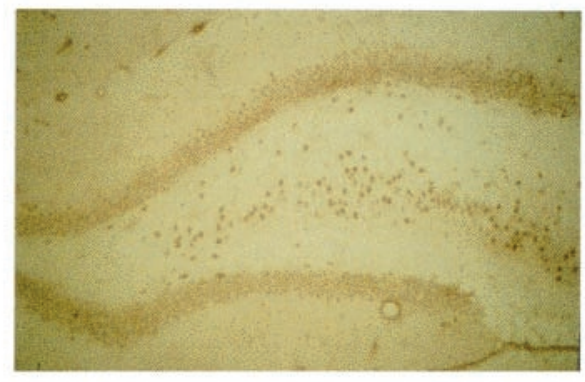

Figure 5. Immuno-identification of $\mathrm{Cx} 36$, using antibodies prepared against skate $\mathrm{Cx} 35$. A, Western blot analysis of adult hippocampus and Cx36-transfected N2A cells. The antibody raised against $\mathrm{Cx} 35$ recognizes a discrete $36 \mathrm{kDa}$ band in protein obtained from Cx36-transfected N2A cells (lane 3 ) and from adult rat hippocampus (lane 1). A very faint signal was detected in parental N2A cells (lane 2), which are neuroblastoma in origin. No signal of the appropriate mobility was detected in the liver, although a higher $M_{\mathrm{r}}$ band was present, indicating that tissues other than brain may express cross-reacting proteins (lane 4). B, Immunostaining (ABC method) of rat brain, showing positive reaction product in pyramidal cells of the hippocampus. Note the reduced reactivity in the granular cells of the dentate gyrus.

a low unitary conductance may offer a distinct advantage over other large-conductance gap junction channels. Neuronal input resistance is generally quite high; thus, a few gap junction channels $\left(g_{\mathrm{j}}: 50-300 \mathrm{pS}\right.$ ) may be sufficient for efficient coupling (coupling coefficient $>0.5$ ). A channel with a low unitary conductance, such as Cx36, may allow cells to achieve a more precise control of the extent of electrical coupling (by varying channel number) than would junctional channels with higher unitary conductances.

Despite the very low unitary conductance of $\mathrm{Cx} 36$ gap junction channels, Lucifer yellow injections demonstrated that these channels are permeable to anions as large as second messenger molecules such as $\mathrm{IP}_{3}$ and cAMP. These findings indicate that $\mathrm{Cx} 36$ channels may provide the substrate for "biochemical coupling" observed in neocortical neurons, which is implicated in the postnatal establishment of synaptic connections (Peinado et al., 1993; Kandler and Katz, 1998).

Macroscopic measurements that used moderately long $V_{\mathrm{j}}$ pulses indicated that current flow through gap junction channels formed of Cx36 responded with monoexponential declines to steady-state levels. The extent of total decline in $I_{\mathrm{j}}$ increased as $V_{\mathrm{j}}$ increased, although even at very high $V_{\mathrm{j}}$ values $( \pm 100 \mathrm{mV})$ a large residual $I_{\mathrm{j}}$ remained. After subtraction of residual conductance $\left(g_{\min }\right)$, steady-state $g_{\mathrm{j}}$ was fit well by a form of the two-state Boltzmann equation, in which the distribution of events in two states is dependent on the energy difference between them. For other connexins these two states appear to be the fully open channel state $(O)$ and the residual conductance state $\left(O_{\mathrm{S}}\right)$. Values for the Boltzmann parameters obtained from macroscopic measurements were $V_{0} \sim \pm 75 \mathrm{mV}, n$ (equivalent gating charges of 


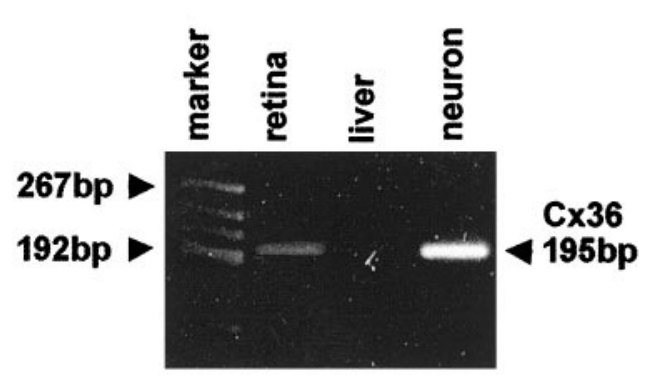

Figure 6. Expression of Cx36 mRNA and functional coupling in cultured mouse hippocampal neurons. $A$, RT-PCR analysis shows the expression of Cx36 mRNA in E18 hippocampal neurons cultured for 2 weeks (lane 4 ) and in extracts of total mouse retina (lane 2); Cx36 mRNA is absent from mouse liver (lane 3). B. Hippocampal neurons allow passage of Lucifer yellow. Lucifer yellow was injected into one cell of a pair (arrow) by using a microelectrode, and the dye transfer (in this case, to an adjacent soma indicated by the asterisk) was observed by using xenon excitation and FITC emission filters. $C$, Electrophysiological recordings between pairs of hippocampal neurons. Junctional currents recorded in response to 60 and $100 \mathrm{mV}$ transjunctional voltage pulses do not exhibit significant relaxation. The arrow indicates the occurrence of spontaneous synaptic currents in these neurons. $D$, The relationship between steady-state junctional conductance $\left(G_{\mathrm{j}, \mathrm{ss}}\right)$ and the transjunctional voltage of hippocampal neurons in four cell pairs. As was observed in transfected cells, the junctional conductance was only weakly sensitive to the transjunctional voltage.
A

B

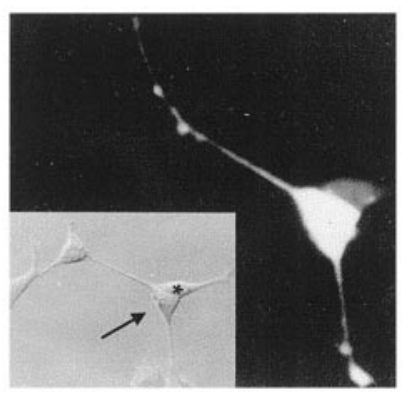

C

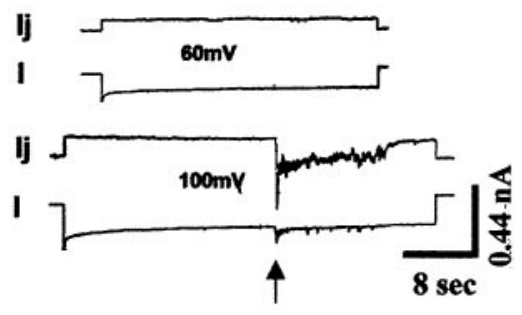

valence $q)=1.75$, and $g_{\min } / g_{\max }=0.52$. The calculated energy difference between the two states $\left(n q \cdot V_{0}\right.$; Harris et al., 1981) is $5.25 \mathrm{kcal} / \mathrm{mol}$. Both the $V_{0}$ and the $g_{\min } / g_{\max }$ values are much higher than for any other mammalian connexin characterized to date, although the values are remarkably similar to those obtained for teleost $\mathrm{C} \times 35$ and $\mathrm{Cx} 34.7$ expressed in Xenopus oocytes (O'Brien et al., 1998), indicating that all of these neuronal connexins form gap junction channels with quite weak voltage sensitivity. The lack of voltage sensitivity of $\mathrm{C} \times 36$ and $\mathrm{Cx} 35$ gap junction channels may provide a mechanism by which to prevent uncoupling during neuronal activity or during neuronal ontogeny, when cells acquire their high resting potentials.

Gap junctions are known to exist in a variety of neurons, including those in CA1 and CA3 regions of the hippocampus (MacVicar and Dudek, 1981; Taylor and Dudek, 1982), preganglionic neurons (Logan et al., 1996) early postnatal neocortex (Gutnick and Prince, 1981; Jefferys and Haas, 1982; Peinado et al., 1993), and the inferior olive (Llinás et al., 1974), in which their role has been hypothesized to provide synchronization of activity. Gap junctions between adult hippocampal neurons are known to allow passage of dye and to be modulated by calcium and $\mathrm{pH}$. However, the identity of the connexin(s) that form gap junction channels in adult hippocampal neurons has not been known. In this study we conclusively demonstrate the presence of Cx36 transcripts in these neurons and show that the low-voltage sensitivity of junctional conductance between these cells is consistent with the possibility that $\mathrm{C} \times 36$ forms these channels. The RNase protection assay shows the presence of Cx36 mRNA and confirms previous reports that hippocampal neurons express this transcript. In addition we demonstrate, using antisera directed to the homologous skate $\mathrm{C} \times 35$, that $\mathrm{C} \times 36$ protein is expressed in hippocampal neurons (see Fig. 5). Taken together, these results conclusively demonstrate that $\mathrm{Cx} 36$ is expressed functionally in adult hippocampal neurons. Properties of Cx36 channels (low unitary conductance, second messenger permeation, and weak voltage dependence) appear to suit ideally the gap junctions formed of this protein for essential roles in signal relay in central and retinal neurons.

\section{REFERENCES}

Banker GA, Cowan WM (1977) Rat hippocampal neurons in dispersed cell culture. Brain Res 126:397-425.

Bennett MVL (1997) Gap junctions as electrical synapses. J Neurocytol 26:349-366 .

Bruzzone R, Ressot C (1997) Connexins, gap junctions, and cell-cell signaling in the nervous system. Eur J Neurosci 9:1-6.

Burt JM, Spray DC (1989) Volatile anesthetics reversibly reduce gap junctional conductance between cardiac myocytes. Circ Res 65:829-837.

Condorelli DF, Parenti R, Spinella F, Trovato Salinaro A, Belluardo N, Cardile V, Ciciata F (1998) Cloning of a new gap junction gene (Cx36) highly expressed in mammalian brain neurons. Eur J Neurosci 10:1202-1208.

Dermietzel R, Spray DC (1993) Gap junctions in the brain: where, what type, how many, and why? Trends Neurosci 16:185-192.

Dermietzel R, Spray DC (1998) From glue ("nervenkitt") to glia: a prologue. Glia 4:1-7.

Gutnick MJ, Prince DA (1981) Dye coupling and possible electrotonic coupling in the guinea pig neocortical slice. Science 211:67-70.

Harris AL, Spray DC, Bennett MV (1981) Kinetic properties of a voltage-dependent junctional conductance. J Gen Physiol 77:95-117.

Jefferys JGR, Haas HL (1982) Synchronized bursting of A1 pyramidal cells in the absence of synaptic transmission. Nature 300:448-450.

Kandler K, Katz LC (1998) Coordination of neuronal activity in developing visual cortex by gap junction-mediated biochemical communication. J Neurosci 18:1419-1427.

Kumar NM, Gilula NB (1996) The gap junction communication channel. Cell 84:381-388.

Llinás R, Baker R, Sotelo C (1974) Electrotonic coupling between neurons in cat inferior olive. J Neurophysiol 37:560-571.

Logan SD, Pickering AE, Gibson IC, Nolan MF, Spanswick D (1996) Electrotonic coupling between rat sympathetic preganglionic neurons in vitro. J Physiol (Lond) 495:491-502.

MacVicar BA, Dudek FE (1981) Electrotonic coupling between pyra- 
midal cells: a direct demonstration in rat hippocampal slices. Science 213:782-785.

Moreno AP, Rook MB, Fishman GI, Spray DC (1994) Gap junction channels: distinct voltage-sensitive and insensitive conductance states. Biophys J 67:113-119.

Moreno AP, Laing JG, Beyer EC, Spray DC (1995) Properties of gap junction channels formed of connexin 45 endogenously expressed in human hepatoma (SKHep1) cells. Am J Physiol 268[Pt 1]:C356-C365.

O'Brien J, al-Ubaidi MR, Ripps H (1996) Connexin 35: a gap-junctional protein expressed preferentially in the skate retina. Mol Biol Cell 7:233-243.

O'Brien J, Bruzzone R, White TW, al-Ubaidi MR, Ripps H (1998) Cloning and expression of two related connexins from the perch retina define a distinct subgroup of the connexin family. J Neurosci 18:7625-7637.

Peinado A, Yuste R, Katz LC (1993) Extensive dye coupling between rat neocortical neurons during the period of circuit formation. Neuron 10:103-114.

Reed KE, Westphale EM, Larson DM, Wang H-Z, Veenstra RD, Beyer EC (1993) Molecular cloning and functional expression of human connexin37, an endothelial cell gap junction protein. J Clin Invest 91:997-1004.

Rozental R, Morales M, Mehler MF, Urban M, Kremer M, Dermietzel R, Kessler JA, Spray DC (1998) Changes in the properties of gap junctions during neuronal differentiation of hippocampal progenitor cells. J Neurosci 18:1753-1762.

Sohl G, Degen J, Teubner B, Willecke K (1998) The murine gap junction gene connexin 36 is highly expressed in mouse retina and regulated during brain development. FEBS Lett 428:27-31.

Spray DC, Harris AL, Bennett MVL (1981) Equilibrium properties of a voltage-dependent junctional conductance. J Gen Physiol 77:77-93.

Taylor CP, Dudek FE (1982) Synchronous neural after-discharges in rat hippocampal slices without active chemical synapses. Science 218:810-812.

Valiunas V, Bukauskas FF, Weingart R (1997) Conductances and selective permeability of connexin 43 gap junction channels examined in neonatal rat heart cells. Circ Res 80:708-719.

Vaney DI (1993) The coupling pattern of axon-bearing horizontal cells in the mammalian retina. Proc R Soc Lond [Biol] 252:93-101.

Veenstra RD, Wang HZ, Beyer EC, Brink PR (1994) Selective dye and ionic permeability of gap junction channels formed by connexin45. Circ Res 75:483-490.

Wong WT, Sanes JR, Wong RO (1998) Developmentally regulated spontaneous activity in the embryonic chick retina. J Neurosci 18:8839-8852.

Zhang D, Mehler MF, Qingbin S, Kessler JA (1998) Development of bone morphogenetic protein receptors in the nervous system and possible roles in regulating TrkC expression. J Neurosci 18:3314-3326. 